\title{
High-Risk Sexual Behavior at a Midwestern University: A Confirmatory Survey
}

By June M. Reinisch, Craig A. Hill, Stephanie A. Sanders and Mary Ziemba-Davis

\begin{abstract}
According to a 1991 study of sexual behavior based on a random sample of heterosexual undergraduates at a Midwestern university, $80 \%$ of the males and $73 \%$ of the females had experienced vaginal or anal intercourse. The average age at first vaginal intercourse was 17.2 years for both sexes. Seventeen percent of the sexually experienced males and $18 \%$ of the sexually experienced females had engaged in heterosexual anal intercourse; among these respondents, the average age at first anal intercourse was 20.3 for males and 19.1 for females. Although less than four years, on average, had elapsed since the respondents had first had vaginal intercourse, males reported an average of 8.0 lifetime vaginal-sex partners and females reported an average of 6.1. Overall, the findings from this random sample of students are similar to those from a 1988 convenience sample of the same college population.

(Family Planning Perspectives, 27:79-82, 1995)
\end{abstract}

$\mathrm{I}$ n a 1988 study based on a convenience sample of undergraduates at a large Midwestern university, we concluded that the majority of college students have engaged in sexual behavior that places them at risk for both sexually transmitted diseases (STDs) and unplanned pregnancy. ${ }^{1}$ Given the methodological value placed on randomly selected samples, however, and our hypothesis that the findings of our study fairly represented the student population sampled, we used probability sampling procedures in a follow-up study of students at the same university. Both studies assessed a wide range of sexual behavior and other factors that affect risk for STDs and unplanned pregnancy, includ-

June M. Reinisch is director emerita and senior research fellow, Stephanie A. Sanders is interim director, Mary Ziemba-Davis is research associate, and Craig A. Hill is associate researcher at The Kinsey Institute for Research in Sex, Gender, and Reproduction, Indiana University, Bloomington. Craig A. Hill is also assistant professor in the Department of Psychological Sciences at Indiana University-Purdue University at Fort Wayne. The research on which this article is based was supported in part by funds raised by Sherry Hackett and the Los Angeles friends of The Kinsey Institute, and questionnaire development was based on work funded in part by National Institute on Drug Abuse grant DA05056 and National Institute of Child Health and Human Development grant HD20263. The authors gratefully acknowledge the assistance of Thomas Albright, Jill Brown, Carolyn Kaufman, Dana Little, William Mirola, Petra Miskus, Joe Nash, Janet Rowland, Jamie Saltzman, Anne Marie Wilson and The Kinsey Institute staff. ing demographic variables, self-labeled sexual orientation, contraceptive use, STD protective measures and STD history.

We examined age at first penile-vaginal intercourse (hereafter referred to as vaginal intercourse) and penile-anal intercourse (hereafter referred to as anal intercourse), the prevalence and frequency of each type of intercourse, and the number of sexual partners for each type of intercourse. As in the previous study, we evaluated each type of behavior by the respondent's sex and by whether his or her current sexual relationship was exclusive or nonexclusive.

\section{Methodology \\ Procedure}

Our first step was to mail letters on Kinsey Institute letterhead to 1,763 randomly selected undergraduate students registered at a large Midwestern university in 1991. To assure the students of the legitimacy of the project, we mailed the letters, which announced our plan to conduct a large survey of college student sexual behavior, several weeks before telephoning prospective participants. The letters stated that names would not be attached in any way to responses and that researchers would talk only to the students themselves to arrange a participation time, a policy that served to protect privacy and confidentiality. Of the 1,029 students who were contacted and potentially available to attend the scheduled data collection sessions, 600 (58\%) agreed to participate.

Students were scheduled in groups of 20 or more to fill out the questionnaire. We held sessions in a large room in which individual desks were arranged far enough apart to ensure privacy. A male researcher and a female researcher remained in the room throughout each session to answer any questions that participants might have.

We administered preliminary instructions to the group as a whole at the beginning of each session, after which we handed out the questionnaire booklets and answered questions. We instructed participants to mark their responses to each question directly on the questionnaire booklet and told them that they could leave at any time. As students left the room, they placed their questionnaire in a box near the exit and we provided them with any educational pamphlets they wanted related to prevention of STDs and human immunodeficiency (HIV) infection.

To ensure the accuracy of the data, two independent coders entered each student's responses into the computer data base and discrepancies between their entries were resolved. We reviewed all questionnaires for consistency and for unusual answers that might have indicated bias, exaggeration, or a misunderstanding of questions. We coded the few suspect responses (fewer than $1 \%$ ) as missing data.

\section{Instrument}

The self-administered questionnaire used in this study, an expanded version of the instrument employed in our 1988 study, ${ }^{2}$ was designed to collect information on sexual behavior and attitudes relevant to the transmission of STDs, including HIV, in a way that enhances accuracy. ${ }^{3}$ For example, the sequence of topics begins with 
Table 1. Percentage distribution of all heterosexual survey respondents, sexually experienced heterosexual respondents, and all undergraduates at a Midwestern university, by selected background characteristics, 1991

\begin{tabular}{|c|c|c|c|c|c|c|}
\hline \multirow[t]{2}{*}{ Characteristic } & \multicolumn{2}{|c|}{ All respondents } & \multicolumn{2}{|c|}{ Sexually experienced } & \multicolumn{2}{|c|}{ All undergraduates* } \\
\hline & $\mathrm{N}$ & $\%$ & $\mathrm{~N}$ & $\%$ & $\mathrm{~N}$ & $\%$ \\
\hline $\begin{array}{l}\text { Sex } \\
\text { Female } \\
\text { Male }\end{array}$ & $\begin{array}{l}344 \\
235\end{array}$ & $\begin{array}{l}59.4 \\
40.6\end{array}$ & $\begin{array}{l}252 \\
188\end{array}$ & $\begin{array}{l}57.3 \\
42.7\end{array}$ & $\begin{array}{l}13,698 \\
11,614\end{array}$ & $\begin{array}{l}54.1 \\
45.9\end{array}$ \\
\hline $\begin{array}{l}\text { Age } \\
18-19 \\
20-21 \\
22-23 \\
24-25 \\
\geq 26\end{array}$ & $\begin{array}{r}213 \\
230 \\
93 \\
18 \\
25\end{array}$ & $\begin{array}{r}36.8 \\
39.7 \\
16.1 \\
3.1 \\
4.3\end{array}$ & $\begin{array}{r}148 \\
167 \\
83 \\
17 \\
25\end{array}$ & $\begin{array}{r}33.6 \\
38.0 \\
18.9 \\
3.9 \\
5.7\end{array}$ & $\begin{array}{l}u \\
u \\
u \\
u \\
u\end{array}$ & $\begin{array}{l}\mathrm{u} \\
\mathrm{u} \\
\mathrm{u} \\
\mathrm{u} \\
\mathrm{u}\end{array}$ \\
\hline $\begin{array}{l}\text { Race } \\
\text { White } \\
\text { Black } \\
\text { Other }\end{array}$ & $\begin{array}{r}528 \\
24 \\
27\end{array}$ & $\begin{array}{r}91.2 \\
4.2 \\
4.7\end{array}$ & $\begin{array}{r}401 \\
19 \\
20\end{array}$ & $\begin{array}{r}91.1 \\
4.3 \\
4.5\end{array}$ & $\begin{array}{r}22,690 \\
991 \\
975\end{array}$ & $\begin{array}{r}92.0 \\
4.0 \\
4.0\end{array}$ \\
\hline $\begin{array}{l}\text { Class } \\
\text { Freshman } \\
\text { Sophomore } \\
\text { Junior } \\
\text { Senior }\end{array}$ & $\begin{array}{l}132 \\
155 \\
138 \\
151\end{array}$ & $\begin{array}{l}22.9 \\
26.9 \\
24.0 \\
26.2\end{array}$ & $\begin{array}{r}95 \\
108 \\
108 \\
128\end{array}$ & $\begin{array}{l}21.6 \\
24.6 \\
24.6 \\
29.2\end{array}$ & $\begin{array}{l}5,227 \\
6,638 \\
5,908 \\
7,539\end{array}$ & $\begin{array}{l}20.7 \\
26.2 \\
23.3 \\
29.8\end{array}$ \\
\hline $\begin{array}{l}\text { Marital status } \\
\text { Ever married } \\
\text { Never married }\end{array}$ & $\begin{array}{r}30 \\
549\end{array}$ & $\begin{array}{r}5.2 \\
94.8\end{array}$ & $\begin{array}{r}29 \\
411\end{array}$ & $\begin{array}{r}6.6 \\
93.4\end{array}$ & $\begin{array}{l}\mathrm{u} \\
\mathrm{u}\end{array}$ & $\begin{array}{l}u \\
u\end{array}$ \\
\hline $\begin{array}{l}\text { Religion of rearing } \\
\text { Protestant } \\
\text { Catholic } \\
\text { Jewish } \\
\text { Other } \\
\text { None }\end{array}$ & $\begin{array}{r}282 \\
159 \\
37 \\
24 \\
77\end{array}$ & $\begin{array}{r}48.7 \\
27.5 \\
6.4 \\
4.2 \\
13.3\end{array}$ & $\begin{array}{r}221 \\
110 \\
27 \\
16 \\
66\end{array}$ & $\begin{array}{r}50.2 \\
25.0 \\
6.1 \\
3.6 \\
15.0\end{array}$ & $\begin{array}{l}\mathrm{u} \\
\mathrm{u} \\
\mathrm{u} \\
\mathrm{u} \\
\mathrm{u}\end{array}$ & $\begin{array}{l}u \\
u \\
u \\
u \\
u\end{array}$ \\
\hline $\begin{array}{l}\text { Region of birth† } \\
\text { Midwest } \\
\text { Northeast } \\
\text { South } \\
\text { West } \\
\text { Outside United States }\end{array}$ & $\begin{array}{r}460 \\
55 \\
40 \\
12 \\
9\end{array}$ & $\begin{array}{r}79.9 \\
9.6 \\
7.0 \\
2.1 \\
1.6\end{array}$ & $\begin{array}{r}348 \\
44 \\
31 \\
8 \\
7\end{array}$ & $\begin{array}{r}79.5 \\
10.0 \\
7.1 \\
1.8 \\
1.6\end{array}$ & $\begin{array}{r}22,191 \\
1,009 \\
1,133 \\
236 \\
695\end{array}$ & $\begin{array}{r}87.8 \\
4.0 \\
4.5 \\
0.9 \\
2.8\end{array}$ \\
\hline $\begin{array}{l}\text { Population of place of } \\
>1,000,000 \\
500,000-999,999 \\
200,000-499,999 \\
100,000-199,999 \\
10,000-99,999 \\
2,500-9,999 \\
<2,500\end{array}$ & $\begin{array}{r}\text { irth } \\
57 \\
98 \\
59 \\
73 \\
253 \\
28 \\
11\end{array}$ & $\begin{array}{r}9.8 \\
16.9 \\
10.2 \\
12.6 \\
43.7 \\
4.8 \\
1.9\end{array}$ & $\begin{array}{r}44 \\
77 \\
44 \\
57 \\
190 \\
19 \\
9\end{array}$ & $\begin{array}{r}10.0 \\
17.5 \\
10.0 \\
13.0 \\
43.2 \\
4.3 \\
2.1\end{array}$ & $\begin{array}{l}\mathrm{u} \\
\mathrm{u} \\
\mathrm{u} \\
\mathrm{u} \\
\mathrm{u} \\
\mathrm{u} \\
\mathrm{u}\end{array}$ & $\begin{array}{l}\mathrm{u} \\
\mathrm{u} \\
\mathrm{u} \\
\mathrm{u} \\
\mathrm{u} \\
\mathrm{u} \\
\mathrm{u}\end{array}$ \\
\hline $\begin{array}{l}\text { College residence } \\
\text { Dormitory } \\
\text { Sorority/fraternity } \\
\text { Off campus } \ddagger \\
\text { With parent/parents }\end{array}$ & $\begin{array}{r}249 \\
67 \\
254 \\
9\end{array}$ & $\begin{array}{r}43.0 \\
11.6 \\
43.9 \\
1.6\end{array}$ & $\begin{array}{r}164 \\
57 \\
211 \\
8\end{array}$ & $\begin{array}{r}37.3 \\
13.0 \\
48.0 \\
1.8\end{array}$ & $\begin{array}{r}9,475 \\
3,147 \\
10,455 \\
660\end{array}$ & $\begin{array}{r}39.9 \\
13.3 \\
44.0 \\
2.8\end{array}$ \\
\hline $\begin{array}{l}\text { Major§ } \\
\text { Business } \\
\text { Social sciences } \\
\text { Humanities/languages } \\
\text { Journalism } \\
\text { Other }\end{array}$ & $\begin{array}{r}123 \\
88 \\
57 \\
51 \\
260\end{array}$ & $\begin{array}{r}21.2 \\
15.2 \\
9.8 \\
8.8 \\
44.9\end{array}$ & $\begin{array}{r}93 \\
69 \\
42 \\
31 \\
205\end{array}$ & $\begin{array}{r}21.1 \\
15.7 \\
9.6 \\
7.0 \\
46.6\end{array}$ & $\begin{array}{l}\mathrm{u} \\
\mathrm{u} \\
\mathrm{u} \\
\mathrm{u} \\
\mathrm{u}\end{array}$ & $\begin{array}{l}\mathrm{u} \\
\mathrm{u} \\
\mathrm{u} \\
\mathrm{u} \\
\mathrm{u}\end{array}$ \\
\hline Total & 579 & 100.0 & 440 & 100.0 & 25,312 & 100.0 \\
\hline
\end{tabular}

*Information was derived from the 1990-91 Enrollment Report Update: A Summary of Second Semesterpublished by the university. Age was not available by the age categories presented for the study sample; the mean age was 20 and the modal age was 19 for the total university undergraduate population. Information on race was obtained from the university registrar's office. Three respondents did not report their year in college. †Based on regional breakdowns from U.S. Bureau of the Census, Statistical Abstract of the United States, 1988 Government Printing Office, Washington, D.C., 1987. ‡Includes those who rented an apartment and those who rented or owned a home. $\S$ Only the major areas of study most frequently listed by the respondents are noted. "Other" is made up of 22 other majors, none of which was mentioned by more than $8 \%$ of respondents. Note: Ns do not always sum to totals because of uncoded, missing or unavailable data.

the least sensitive issues (e.g., demographic information and nonsexual questions) and ends with the most explicit questions on sexual behavior. Behavioral questions are asked before questions on sexual knowledge and attitudes to minimize the extent to which concerns about social acceptability and desirability might influence the reporting of actual behavior.

Questions about behavior are specific and explicit, avoiding the use of euphemisms. All respondents are asked to respond to questions about their sexual activities with male and female partners, re- gardless of the respondent's self-reported sexual orientation. (Such labels do not necessarily accurately predict sex of partner and type of activity. ${ }^{4}$ ) The questionnaire asks about behavior in the last 12 months and across the respondent's lifetime.

\section{Data Analysis}

We used chi-square analyses to test associations between the independent variables (sex of respondent and type of sexual relationship) and the dichotomously defined dependent variables. We conducted an analysis of variance for each type of behavior measured on a continuous scale. The Tukey Honestly Significant Difference method was used for post-hoc comparisons.

\section{Results}

Characteristics of Participants

When participants were asked to indicate their sexual orientation, $96.5 \%$ labeled themselves as heterosexual or straight; $1.2 \%$ labeled themselves as homosexual, lesbian or gay; and 2.3\% labeled themselves as bisexual. To determine the extent to which people who label themselves as heterosexual engage in sexual behavior that may place them at increased risk of HIV infection, we based our analyses only on the 579 respondents (344 females and 235 males) who labeled themselves as heterosexual.

Table 1 presents sex, age, race, class standing, marital status, religion of rearing, region of birth, population of birthplace, type of college residence and major area of study, both for all heterosexual respondents and for those who were sexually experienced (defined as having engaged in either vaginal or anal intercourse at some time in their life). The table also provides information about the demographic characteristics of the university's general undergraduate population (restricted to U.S. citizens to match the sampling procedures for the current study). The mean age of heterosexual respondents (range, 18-43) was 20.7, their median age was 20.0 and their modal age was 19.0.

The demographic characteristics of this sample are comparable to those of respondents in our 1988 study, although the current sample is more evenly divided between the sexes. As in the convenience sample in the earlier study, about half of the respondents in this random sample were from towns of fewer than 100,000 inhabitants. Therefore, we considered it likely that many respondents were raised in a sociopolitical climate that could be considered moderate to conservative. When participants were asked to rate their general political position or outlook on a five-point Likert scale, $67 \%$ 
Table 2. Selected measures of sexual experience among respondents who had ever had intercourse, by sex

\begin{tabular}{|c|c|c|c|c|}
\hline \multirow[t]{2}{*}{ Measure } & \multicolumn{2}{|l|}{ Males† } & \multicolumn{2}{|l|}{ Females† } \\
\hline & $\%$ or mean & $\mathrm{N}$ & $\%$ or mean & $\mathrm{N}$ \\
\hline \multicolumn{5}{|l|}{ Time since first intercourse } \\
\hline Mean no. of years & 3.9 & 187 & 3.8 & 252 \\
\hline \multicolumn{5}{|l|}{ Vaginal intercourse } \\
\hline$\%$ ever had vaginal intercourse & 100.0 & 188 & 100.0 & 252 \\
\hline Mean age at first experience & 17.2 & 188 & 17.2 & 252 \\
\hline Mean frequency in past year & 62.9 & 182 & 53.2 & 245 \\
\hline Mean frequency in past month & 6.8 & 187 & 6.1 & 251 \\
\hline Mean no. partners ever & 8.0 & 187 & 6.1 & 252 \\
\hline Mean no. partners in past year & 2.6 & 187 & 1.9 & 250 \\
\hline \multicolumn{5}{|l|}{ Anal intercourse } \\
\hline$\%$ ever had anal intercourse & 17.1 & 32 & 17.9 & 45 \\
\hline Mean age at first experience & 20.3 & 32 & 19.1 & 45 \\
\hline Mean frequency in past year & 1.8 & 32 & 2.5 & 41 \\
\hline $\begin{array}{l}\% \text { having anal intercourse in } \\
\text { past yearf }\end{array}$ & 688 & & 488 & 20 \\
\hline \multicolumn{5}{|l|}{$\%$ having anal intercourse } \\
\hline in past month§ & 25.8 & 8 & 15.6 & 7 \\
\hline Mean no. partners ever & 1.6 & 32 & 1.1 & 45 \\
\hline Mean no. partners in past year & 0.8 & 32 & 0.5 & 42 \\
\hline \multicolumn{5}{|l|}{ Current relationship type } \\
\hline Exclusive & 52.9 & 99 & 59.9 & 151 \\
\hline Nonexclusive & 18.2 & 34 & 11.9 & 30 \\
\hline No relationship & 28.9 & 54 & 28.2 & 71 \\
\hline
\end{tabular}

†Based on total samples of 188 males and 252 females; Ns differ across types of behavior because not all respondents answered all questions. $\neq$ Based on 32 males and 41 females. $\S$ Based on 31 males and 45 females. sexually experienced male and 252 sexually experienced female respondents had first had intercourse (Table 2). All reported having had vaginal intercourse. The mean age at first vaginal intercourse was about 17.2 years for both males and females. Males reported a higher frequency of vaginal intercourse for the past year $(\mathrm{p}<.081)$ and the past month than did females. The average lifetime number of vaginal-sex partners was 8.0 for males and 6.1 for females, and the average number in the last year was 2.6 for males and 1.9 for females $(\mathrm{p}<.086)$.

Seventeen percent of sexually experienced males and $18 \%$ of sexually experienced females had engaged in anal inidentified themselves as "moderate," while smaller proportions identified themselves as "conservative" $(12 \%)$ or "liberal" $(20 \%)$. We obtained nearly identical proportions when we considered only sexually experienced respondents.

\section{Sexual Behavior}

The prevalence of vaginal and anal intercourse was determined by the number of respondents who reported an age at which they first engaged in those behaviors. Eighty percent of the males and $73 \%$ of the females had ever had intercourse. On average, 3.8 years had elapsed since the 188

tercourse, a finding that is consistent both with results from our earlier study and with the few other studies that have examined the prevalence of this behavior. ${ }^{5}$ The mean age at first anal intercourse was 20.3 for males and 19.1 for females. Of respondents who had ever engaged in anal intercourse, $25 \%$ of males and $16 \%$ of females had done so in the previous month. (One male did not provide this information.) In addition, $69 \%$ of the males and $49 \%$ of the females who had ever had anal intercourse had done so in the previous year. (Four females did not provide this information.) Half of those who had ever en-

Table 3. Selected measures of sexual experience among respondents who had ever had intercourse, by type of relationship

\begin{tabular}{|c|c|c|c|c|c|c|}
\hline \multirow[t]{2}{*}{ Measure } & \multicolumn{2}{|c|}{ Exclusive } & \multicolumn{2}{|c|}{ Nonexclusive } & \multicolumn{2}{|c|}{ No relationship } \\
\hline & $\begin{array}{l}\% \text { or } \\
\text { mean }\end{array}$ & $\mathrm{N}$ & $\begin{array}{l}\% \text { or } \\
\text { mean }\end{array}$ & $\mathrm{N}$ & $\begin{array}{l}\% \text { or } \\
\text { mean }\end{array}$ & $\mathrm{N}$ \\
\hline $\begin{array}{l}\text { Time since first intercourse } \\
\text { Mean number of years }\end{array}$ & $4.1^{*}$ & 250 & $4.1^{*}, \dagger$ & 64 & $3.1 \dagger$ & 125 \\
\hline $\begin{array}{l}\text { Vaginal intercourse } \\
\text { Mean age at first experience } \\
\text { Mean frequency in past year } \\
\text { Mean frequency in past month } \\
\text { Mean no. partners ever } \\
\text { Mean no. partners in past year }\end{array}$ & $\begin{array}{r}17.3^{\star} \\
78.1^{\star} \\
9.3^{\star} \\
6.0^{\star} \\
1.6^{\star}\end{array}$ & $\begin{array}{l}250 \\
242 \\
249 \\
250 \\
249\end{array}$ & $\begin{array}{r}16.5 \dagger \\
47.6 \dagger \\
6.1 \dagger \\
15.5 \dagger \\
5.3 \dagger\end{array}$ & $\begin{array}{l}64 \\
64 \\
64 \\
64 \\
64\end{array}$ & $\begin{array}{r}17.3^{\star} \\
21.0 \ddagger \\
0.8 \ddagger \\
4.5^{\star} \\
1.9^{\star}\end{array}$ & $\begin{array}{l}125 \\
121 \\
125 \\
125 \\
124\end{array}$ \\
\hline $\begin{array}{l}\text { Anal intercourse } \\
\% \text { ever had anal intercourse } \\
\text { Mean age at first experience } \\
\text { Mean no. partners ever } \\
\text { Mean no. partners in past year }\end{array}$ & $\begin{array}{c}19.6 \\
19.9 \\
1.4 \\
0.1^{\star}\end{array}$ & $\begin{array}{r}250 \\
49 \\
48 \\
248\end{array}$ & $\begin{array}{c}25.0 \\
19.6 \\
1.3 \\
0.2^{\star}\end{array}$ & $\begin{array}{l}64 \\
16 \\
16 \\
62\end{array}$ & $\begin{array}{c}9.6 \\
18.3 \\
1.1 \\
0.0 \dagger\end{array}$ & $\begin{array}{r}125 \\
12 \\
12 \\
124\end{array}$ \\
\hline
\end{tabular}

gaged in anal intercourse had done so more than one time in the past year.

The average lifetime number of anal-sex partners was 1.6 for males and 1.1 for females, while the average number in the last year was 0.8 for males and 0.5 for females ( $\mathrm{p}<.082)$. Respondents who had engaged in anal intercourse reported having engaged in vaginal intercourse with an average of 12 partners in their lifetime, compared with almost six partners among those without such experience $(\mathrm{p}<.001$; not shown), suggesting that participation in anal intercourse may be a marker for other high-risk behavior.

\section{Type of Relationship}

Fifty-three percent of the sexually experienced males and $60 \%$ of the sexually experienced females were involved in an exclusive relationship at the time of the study (Table 2), proportions similar to those in our 1988 study. However, like their counterparts in the earlier study, those involved in sexually exclusive relationships reported an average of more than one partner in the year before the survey (Table 3), perhaps an indication of the serial sexual exclusivity that appears to be characteristic of this age-group. ${ }^{6}$

The proportions of males and females in a sexually nonexclusive relationship (18\% of males and $12 \%$ of females) were also similar to those in the earlier study. As Table 3 shows, these respondents reported significantly more partners in the past year and in their lifetime than did respondents in an exclusive relationship or those not in a relationship ( $p<.05$ for each comparison). ${ }^{*}$ As in the earlier study, although respondents in nonexclusive relationships reported the most partners, they did not report the greatest frequency of vaginal intercourse; thus, such respondents probably were not exaggerating their reports of sexual behavior. Respondents in nonexclusive relationships were also significantly younger at first vaginal intercourse than were other sexually experienced respondents (16.5 years vs. 17.3 years; not shown).

\section{Discussion}

With few exceptions, the average values for both background variables and for sexual behavior obtained in this study were consistent with those found in our 1988 study. The comparability of findings from

*The category "not in a relationship" is likely to include both respondents who were between relationships at the time of the survey and respondents who tended not to form ongoing relationships. In contrast, those in a nonexclusive relationship were involved in an ongoing but nonmonogamous relationship. 
the 1988 convenience sample and the current random sample suggests that the findings of our 1988 study fairly represented the student population sampled.

The few differences between the two studies generally involved the relationship between sex and sexual behavior or between type of sexual relationship and sexual behavior. Significant differences by sex of respondent were found in the 1988 study-but not in the current study-for age at the time of the survey, time since first vaginal intercourse, frequency of vaginal intercourse in the last month and frequency of anal intercourse in the last year. The current study found marginally significant differences between males and females for three other variables: frequency of vaginal intercourse in the past year, number of vaginal-sex partners in the last year and number of anal-sex partners in the last year; in the first study, only the first of these showed a significant difference by sex. It is possible that the difference between males and females in age at the time of the survey found in the 1988 study may account for the few differences observed between the two studies.

In contrast to our 1988 study, the current study revealed differences by type of sexual relationship in age at the time of the survey and time since first sexual intercourse. Similar differences in frequency of vaginal intercourse in the last month according to type of sexual relationship were found in both studies.

For a number of variables in our 1988 study, sex of respondent interacted statistically with type of sexual relationship, but we found no such relationships in the current study. These variables were time since first vaginal intercourse, percentage of sexually experienced respondents who had ever engaged in anal intercourse and number of vaginal-sex partners (ever and in the last year). In all cases, values for males and females were similar in the present study; differences occurred only as a function of type of sexual relationship. Similarly, in our 1988 study, the proportion of males involved in a nonexclusive sexual relationship was significantly greater than the proportion of females, while the difference in the current study was not significant.

In general, where differences between males and females were found in the first study - either as a simple effect or in interaction with type of sexual relationshipthe type of sexual relationship in itself had a significant effect in the second study. Thus, type of sexual relationship, regardless of whether an individual is male or female, will ultimately prove to be one of the most reliable predictors of relative risk associated with sexual behavior patterns.

As in the convenience sample used in our 1988 study, the majority of the heterosexual college students in this randomly selected sample had engaged in sexual behavior that placed them at risk for both STDs and unplanned pregnancy. Only $20 \%$ of males and $27 \%$ of females had never experienced vaginal or anal intercourse; these findings are consistent not only with the results of our 1988 study, but also with the ranges reported by other investigators. ${ }^{7}$ The average age at first vaginal intercourse was 17 for both males and females, $17 \%$ of males and $18 \%$ of females had engaged in anal intercourse at some time in their life and 38\% of sexually experienced males and $36 \%$ of sexually experienced females had engaged in vaginal intercourse with more than five partners in their lifetime. Although the average time since first intercourse was less than four years, males reported an average of eight female partners and females reported an average of six male partners.

The extent to which the behavior of these students places them at risk is demonstrated by their limited use of contraceptives and prophylactics and by the prevalence of STDs. As in the earlier study, approximately one-third of the respondents who had engaged in vaginal or anal intercourse during the previous year either had not used any form of protection against STDs or had used a method that provides little or no protection from either STDs or pregnancy (i.e., withdrawal or rhythm) at least some of the time (not shown). The last time they had intercourse, more than two in 10 had used no method or had used withdrawal or rhythm, more than five in 10 had used an effective birth control method that provided no protection from STDs (the pill, tubal ligation, vasectomy or the IUD), only about three in 10 had used condoms, and fewer than one in 10 had used a barrier method that offers more limited protection from STDs (foam, spermicide, the sponge, the diaphragm or the cervical cap).

As a result, one in five males and nearly one in three females had been infected with an STD such as anogenital warts, chlamydia, gonorrhea, hepatitis B, herpes, pelvic inflammatory disease, pubic lice or scabies, syphilis or trichomoniasis. The proportion of women who had been diagnosed with an STD was higher in the present sample than in the earlier sample, by an increment of approximately 10 percentage points.

Given that $80 \%$ of the respondents considered themselves politically moderate or conservative, their risky sexual behavior cannot be attributed to generally liberal attitudes. As we argued in our report on the 1988 study, data based on Midwestern college students may provide conservative estimates of high-risk sexual behavior for the U.S. population in this age-group because the Midwest tends to be among the more conservative regions of the country, particularly on issues related to gender and sexuality. The highly consistent results of the two studies provide strong evidence that high-risk sexual behavior persists among college-educated persons, even in an age of increased public education about the risks of such behavior.

\section{References}

1. J. M. Reinisch et al., "High-Risk Sexual Behavior Among Heterosexual Undergraduates at a Midwestern University," Family Planning Perspectives, 24:116-121 \& 145, 1992. 2. Ibid.

3. J. M. Reinisch, S. A. Sanders and M. Ziemba-Davis, "The Study of Sexual Behavior in Relation to the Transmission of Human Immunodeficiency Virus: Caveats and Recommendations," American Psychologist, 43:921-927, 1988; J. M. Reinisch, M. Ziemba-Davis and S. A. Sanders, "Sexual Behavior and AIDS: Lessons from Art Throughout History and Sex Research Conducted in the Last Forty Years," in B. Voeller, J. M. Reinisch and M. Gottlieb, eds., AIDS and Sex: An Integrated Biomedical and Biobehavioral Approach, Oxford University Press, New York, 1990, pp. 37-80; and A. C. Kinsey, W. B. Pomeroy and C. E. Martin, Sexual Behavior in the Human Male, W. B. Saunders, Philadelphia, 1948

4. J. M. Reinisch, S. A. Sanders and M. Ziemba-Davis, 1988, op. cit. (see reference 3); ——, "Self-Labeled Sexual Orientation and Sexual Behavior: Considerations for STD-Related Biomedical Research and Education," in M. Stein and A. Baum, eds., Perspectives on Behavioral Medicine (in press); and L.S. Doll et al., "Homosexually and Nonhomosexually Identified Men Who Have Sex with Men: A Behavioral Comparison," Journal of Sex Research, 29:1-14, 1992.

5. J. M. Reinisch, S. A. Sanders and M. Ziemba-Davis, 1988, op. cit. (see reference 3); R. T. Michael et al., Sex in America: A Definitive Study, Little, Brown, Boston, 1994; K. L. Kotloff et al., "A Voluntary Serosurvey and Behavioral Risk Assessment for Human Immunodeficiency Virus Infection Among College Students," Sexually Transmitted Diseases, 18:223-227, 1991; N. E. MacDonald et al., "High-Risk STD/HIV Behavior Among College Students," Journal of the American Medical Association, 263:3155-3159, 1990; and I. L. Lottes, "Nontraditional Gender Roles and the Sexual Experiences of Heterosexual College Students," Sex Roles, 29:645-669, 1993.

6. K. Tanfer and J. J. Schoorl, "Premarital Sexual Careers and Partner Change," Archives of Sexual Behavior, 21:45-68, 1992.

7. J. O. G. Billy et al., "The Sexual Behavior of Men in the United States," Family Planning Perspectives, 25:52-60, 1993 . J. DeLamater and P. MacCorquodale, Premarital Sexuality: Attitudes, Relationships, Behavior, University of Wisconsin Press, Madison, 1979; M. King and D. Sobel, "Sex on the College Campus: Current Attitudes and Behavior," Journal of College Student Personnel, 16:205-209, 1975; N. E. MacDonald et al., "High-Risk STD/HIV Behavior Among College Students," Journal of the American Medical Association, 263:3155-3159, 1990; P.D. Bishop and A. Lipsitz, "Sexual Behavior Among College Students in the AIDS Era: A Comparative Study," Journal of Psychology and Human Sexuality, 4:135-148, 1991; and F. W. Finger, "Changes in Sex Practices and Beliefs of Male College Students over 30 Years," Journal of Sex Research, 11:304-317, 1975. 